\title{
Rammed earth walls in the late middle age castles in the actual province of Soria, Spain
}

\author{
I.J. Gil Crespo \\ Universidad Politécnica de Madrid, Spain
}

\begin{abstract}
This paper analyzed the building techniques based in the use of rammed earth in the Late Medieval fortifications in the province of Soria, Spain. The manorial castles of Serón de Nágima and Yanguas were built completely with rammed earth. However, these techinques are different. Through the study of the constructive signals, we can reconstruct the constructive process and made an hypothesis of the auxiliary scaffolding necessary for the construction. After, other four cases in which there is presence of rammed earth are described: Ágreda, Arcos de Jalón, Caracena and the tower of Martín González or castle of La Raya (the Border). Rammed earth is used in some secondary architectural elements and also as a filling of the masonry walls, but somtimes there are ancient rammed earth walls overlaid with stone masonry
\end{abstract}

\section{AIMS AND METHOD}

The communication is part of the doctoral thesis that the author is developing under the direction of Prof. Ph. D. Santiago Huerta Fernández and Prof. Ph. D. Luis Maldonado Ramos in the School of Architecture of Madrid. More of 30 castles were studied and classified by means of their constructive techniques. Some of them, those in which the rammed earth is used, will be developed and analyzed by graphical methods in the communication.

The research was made through field works in which layouts are made and constructive data are taken. These data are supplemented with those extracted from the literature review.

The data are collected in data-sheets in which typological, defensive and constructive data are contained. The surveys has been made through the data taken on site and photogrametry techniques.

The constructive lecture of the paraments and walls help to compare several masonry works in the territory. This comparison serves to raise the building dating. This comparison serves to raise the dating of the building, which has been difficult to estimate using only historiographical or stylistic methods.

Through the putlog holes left in the masonry by the scaffolding we can study the systems and processes of the building. The architectonical lecture of these holes helps to us to know the auxiliary methods and the constructive processes.

Alfonso I, king of Aragón, reconquered the actual province of Soria, Spain, between 1119 and 1124. His stepson, Alfonso VI of Castile claimed after for these territories. In this moment, the warlike relationship between the Crowns of Castile and Aragon started. Confront was along the whole Late Middle Age. The method for the frontier definition and defense consisted in its systematic fortification (Gil Crespo 2013).

Many of these castles were built using the rammed earth, as the case of the castles of Serón de Nágima and Yanguas. In other occasions, there are only some walls of the castle which wre built with this constructive technique. We can observe this item in the castles of Caracena and Berlanga de Duero. At last, we have note that the rammed earth was used as fill of the walls which its external layer was built with masonry, by example in the castles of La Raya, Arcos de Jalón or Ágreda.

\section{CONSTRUCTIVE MATERIALS AND TECHNIQUES}

The choice of the constructive material of the castles tends to be those that is found and used in the near area: it is a question purely vernacular. However, there are some exceptions, such as the castle of Yanguas. This castle is placed in an stone area but it, is a fortress erected entirely with rammed earth. These exceptions are rare and seem to respond to reasons of cultural influence.

Stone is the material used for the construction of the border fortifications between the crowns of Castile and Aragon in the province of Soria. Brick has had a second rol: in the castle of Arcos de Jalon is used in a mix masonry of brick rows 


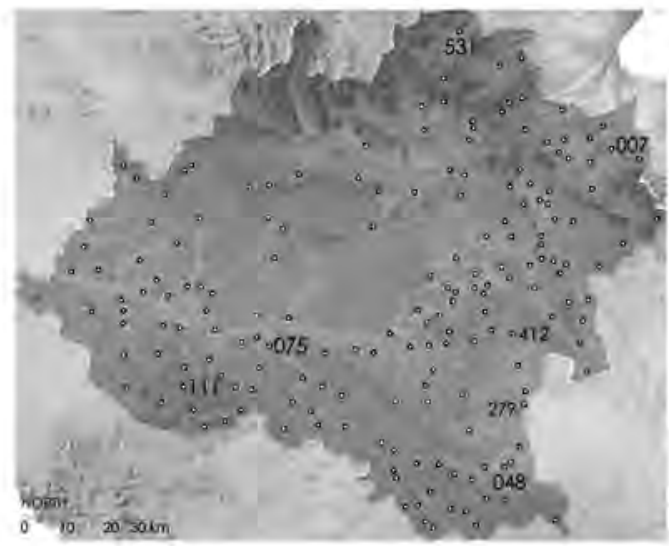

Figure 1. Situation map where are signed the places named in the paper: Agreda (007), Arcos de Jalón (048), Berlanga de Duero (075), Caracena (111), La Raya (279C), Serón de Nágima (412) and Yanguas (531). Also are signed the whole castles of the province (Credits: Author).

between stone. Brick also defines the putlog holes where the scaffolding was put. The main tower or keep built in the late Middle Ages in the ancient caliphal fortress in Gormaz has also brick in rows and in the corners.

Rammed earth is only used as unique construction technique in two cases: the castles of Serón de Nágima and Yanguas. However, there are other cases in which rammed earth is used as a building material in the fillings of some stone walls in the castles of Caracena, Berlanga de Duero, Arcos de Jalón, La Raya or Ágreda.

\section{CASTLES COMPLETELY BUILT WITH RAMMED EARTH}

\subsection{Serón de Nágima}

This fortress is named many times during the late medieval confrontations between Castile and Aragón. That responds to the fact that it is located in one of the main routes between Jalón's and Duero's valleys during the frontier wars, mainly the Guerra de los Dos Pedros-Two Pedros Warthat happened between 1356 and 1369 .

News about the city of Serón are dated since 13 th Century, but it is possible that the castle were built later in the 14th of 15th Century. However, many investigators has dated the castle as muslim, that is: previous to the 12 th Century when the territory is reconquered. The reason for what they have dated the castle is its constructive technique of rammed earth, because there is any artistic element. We think, comparing the construction with

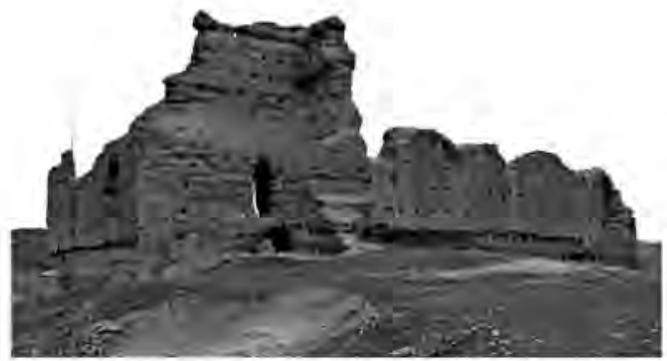

Figure 2. Southern view of Serón de Nágima castle (Credits: Author).

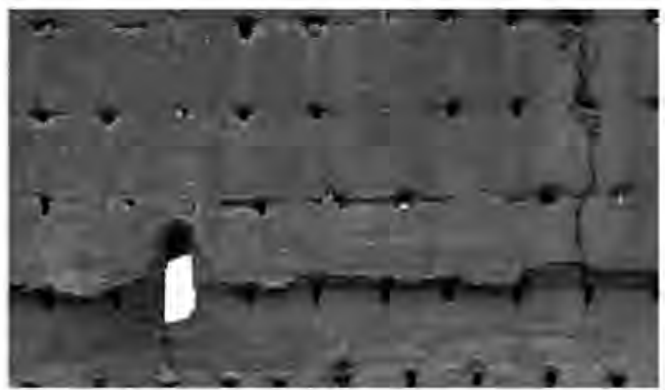

Figure 3. Calicastrado layer, putlog holes and arrowslit in the western wall of Serón de Nágima's castle (Credits: Author).

other castles of rammed earth, that the erection of the castle was around the Late Middle Age and in only one constructive stage.

The construction of the castle of Serón is profusely analyzed in a previous publication (Gil Crespo 2012), so that here we only will sign any constructive data. The walls are $2.40 \mathrm{~m}$ width at the lower part and 2.70 in the upper. The difference leads us to think that a skirting board protected the lower part of the wall. It could be ashlars masonry. The upper part of the wall has an outer layer of lime mortar coat about $10 \mathrm{~cm}$ thick, commonly known as calicastrado. It is built by rammed earth levels around $90 \mathrm{~cm}$ high. Batches of compacted earth can be observed. The average thickness is between six and seven centimeters.

The presence of the putlog holes of the wooden cross ties helps us to reconstruct the process of the walls construction. The distance between these putlog holes to each other is about $70 \mathrm{~cm}$. They pass ever from one side of the wall to the other side. In some of them, the superficial sealing remains. This stopper is made with a fill of rubble, gravel, mud and lime. None of them shows any rest of the wooden cross ties. These signs are the negative of the wooden beams used both as wooden cross ties of the formwork as scaffolding to build 
the walls. Two wooden cross ties' sizes have been documented: $8 \times 15 \mathrm{~cm}$ and $10 \times 10$.

The upper part of the walls was finished off with lime mortar rubble, constructed with the same technique of rammed earth formwork. This way, the head of the wall would be protected from impacts and erosion with a more resistant material.

In the walls preserved from the Serón de Nágima castle, we can see several voids. In the western wall there is a big high window, which could have perhaps been the access to the site. However, the most exceptional holes are some aspilleras or saeteras - loopholes or arrowslit: defensive holes with vertical form formed by a formwork inside the rammed earth.

The encounter among the several phases of the building is done by a inclined joint. It is the result of the shortening of the length of each batch. In this manner ensures proper interlocking between the different phases of work. The inclinations of the different joints are parallel.

\subsection{Yanguas}

The castle of Yanguas is placed in the western end of the promontory on which the town is, between the open valleys of two streams that drain into the river Cidacos. It is a quadrangular castle with towers at the corners. It has got a second outer masonry wall, of which only the southern, western and northern sides are preserved. The gate to the first enclosure is in the western end, while the door of the castle is situated on the opposite side. There also is a wicket in this inner enclosure in western wall. The castle is under restauration by architect José Francisco Yusta Bonilla.

The castle is entirely built with rammed earth technique. It has got four towers in the corners of its quadrangular plant that close a courtyard that was surrounded by columns, which appeared in archaeological excavationstions (Espinosa de los Monteros and Martín-Artajo Saracho 1974, 467). The battlements were finished off with a walkway protected by merlons with loopholes.

On the eastern side, which is near the square of the town, is where there is more holes and windows part of the loopholes that are distributed throughout the remaining walls. All holes were formed with a formwork in the same process by which they were built the rammed earth walls.

In the Corpus de los castillos medievales de Castilla-Corpus of the medieval castles of Castile - it is indicated that «the palace seems to be Arab» (Espinosa de los Monteros and MartínArtajo Saracho 1974, 467), perhaps confused by its construction technique. The news we have begin to appear at the end of the Middle Ages. Its first owners were Don Pedro and Don Diego Jimenez. In 1366 the owner is Juan Ramirez de
Arellano, M. de Cameros (Fernandez de Sosa 1998).

The construction technique is uniform. It is established on a significantly ground plane. The difference in level between the highest and the lowest points, which occurs in the southwest corner, is just a constructive row. The rammed earth walls have got ten full levels plus another one for the battlements. The towers rise six wires above the walls, which must also include another one for the formation of battlements. The height of each constructive row comes to be around $90 \mathrm{~cm}$ and the thickness of the wall is about two meters.

It notes, for the characteristic vertical joint between the rammed earth boxes, that the formwork for rammed earth was complete. At some this encounter is taken to make it more spacious and open a loophole, with a small wooden table lintel.

The putlog holes are spaced about $70 \mathrm{~cm}$. There are three for each rammed earth box and they are not passant. Its dimensions indicate that the crossbeams have a square squareness between 6 and $8 \mathrm{~cm}$ across, approximately.

The construction of the holes is formed with the same formwork molds. In the western wall of the southeast tower there is a hole shaped arc. It was built by using a formwork with that form inside the box in which the earth is rammed. Some holes in the southern wall in the same tower have wooden lintels. The encounter between the walls and the towers is not always locked. This indicates that the tower is constructed first and construction proceeded southwestern according clockwise.

\section{OTHER CASTLES WITH ELEMENTS OF RAMMED EARTH}

\subsection{Rollo tower in Ágreda}

The tower of the Rollo of the city wall of Ágreda is at the northwest end of the third walled enclosure. It is a square-plan tower and the gate is placed high. It has a top battlement. The tower is built with stone masonry with ashlar at the corners. However, in the section of wall that is attached to this tower it is observed that when the external layer of stone, the filling of the wall is built with rammed earth. There are preserved four constructive rows plus another built with lime and mortar masonry.

The stone layer seems to be the formwork to the rammed earth because the putlog holes can be seen crossing both materials and the constructive levels are coincident. 


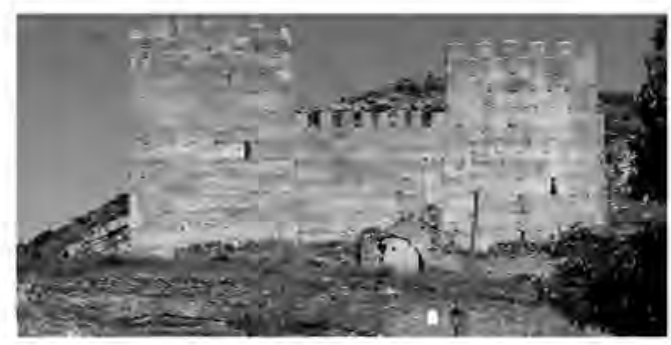

Figure 4. Western façade of Yanguas castle (Credits: Author).

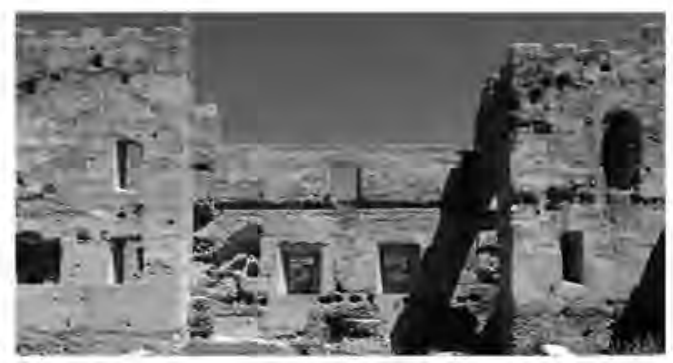

Figure 5. Interior courtyard of Yanguas castle (Credits; Author).

\subsection{Arcos de Jalón}

In the eastern wall of the castle of Arcos de Jalon there is a rectangular reinforcement as a turret. When the external layer is collapsed, the rammed earth filling is visible.

This tower seems to be an addition. There is no continuity in the encounter between its masonry and the wall. The head of the tower-its dimensions are about $3 \times 9 \mathrm{~m}$ is very deteriorated and it has lost both the coronation as part of the external stone and brick, exposing the earth filling. It is observed that the putlog holes penetrate into the wall. Their depth has not been possible to be measured because is inaccessible. The holes are formed with a brick that is placed over, without side bricks as in the rest masonry of the castle.

The stone size and dimensions of the bricks are similar to those of the rest of the masonry of the castle, which presumably, though not were constructed at a time, are of the same era. Perhaps it was added to reinforce - both defensively and structurally - the northeast corner of the wall. In this case, rammed earth has been used as filling.

\subsection{Caracena}

The castle of Caracena is placed in the south of the town, between the Gargantas and Pilares streams, which go by a deep ravine. It has got two lines of

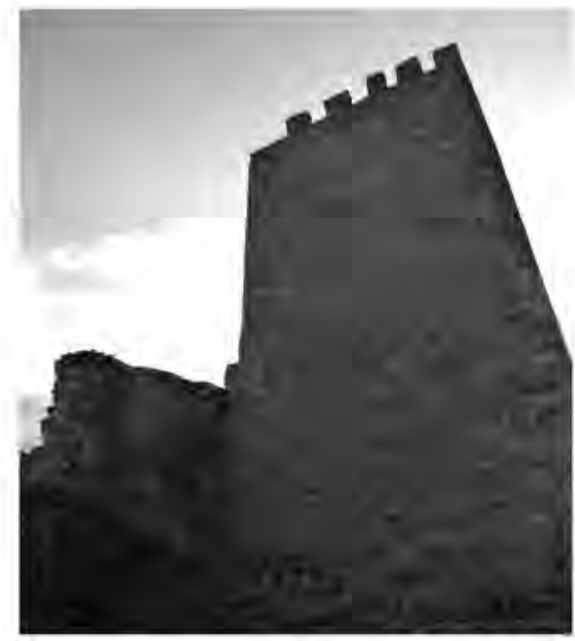

Figure 6. Rollo tower in the Agreda walls. In the inner part, at right, it is the rammed earth wall (Credits: Author).

wall and an outer barbican, on the western side. The shape of the courtyard is trapezoidal with the keep in the south corner. On the eastern side and from the noro-eastern corner of the keep, perpendicular to the castle wall, starts a transverse wall that cuts off the plain between the two ravines. Possibly it is a coracha or protective wall for communication with Pilares stream for the water supply.

The external stone layer of this wall has gone down and it can be seen the inside masonry of rammed earth. The constructive rows are sloped, as the slope of the ground. These rows are about about $80 \mathrm{~cm}$ height and are formed by successive horizontal compacted layers of about $7 \mathrm{~cm}$. The putlog holes are distributed each $100 \mathrm{~cm}$ approximately. They are not passant and there still are some flat wooden crossbars inside flat ties. Construction joints are horizontal, because the rows are inclined.

In the inner part of the southern wall of the courtyard is also observed that the inside part is built with rammed earth.

\subsection{Martin González Tower or Castle of La Rava}

Martín González Tower is located on the edge of the moorland of lime stone surrounding the Nágima river valley on the border between Castile and Aragon: hence its nickname the Castle of $\mathrm{La}$ Raya.

The castle consists in a rectangular tower and the walls around a courtyard. The whole are in an advanced state of ruin. The tower, located on the western side, is about 25 meters high and a base approximately $10 \times 8 \mathrm{~m}$ in plant. The walled 


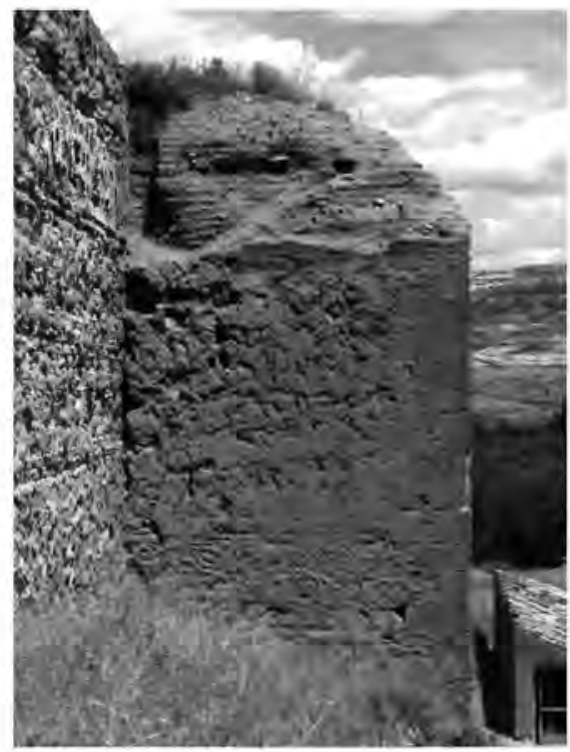

Figure 7. Turret with rammed earth filling in the eastern wall of the castle of Arcos de Jalón (Credits: Author).

courtyard is quasi rectangular about $18 \times 22 \mathrm{~m}$. In the center there is an underground well, excavated in the limestone. It remains several cubes and doors in the wall.

The unique tower-keep is in the west side. The inner dimensions are about $4.60 \times 6.10 \mathrm{~m}$. It only remains the western wall and part of the northern and southern walls. The entrance is on the ground floor and it is realized through a reduced arch. There is the traces of three levels of floors and remnants of the wooden beams in the putlog holes. The top floor was covered with a barrel vault and the roof was an crenellated top.

The walls are about two meters thick. There are rests of four cubes attached to the wall: three of them are semi-cylindrical.

In the west wall, and protected by the tower, it is the access to the castle. It is a reduced arch with the jambs built of ashlar masonry. There still is the hole to keep the wooden cross piede that closed the door.

The southern wall seems to be filled with rammed earth. The putlog holes are passant and they are formed with a ceiling of rocks and stones which facilitates the extraction of the wooden crossbar once finished the construction of the rammed earth box. These boxes are about $120 \mathrm{~cm}$ height with earth tiers of about $6 \mathrm{~cm}$. The rest of the walls, including the tower, are filled with stone and mortar. In this case, the rammed earth seems to be and old masonry recover with a stone layer.

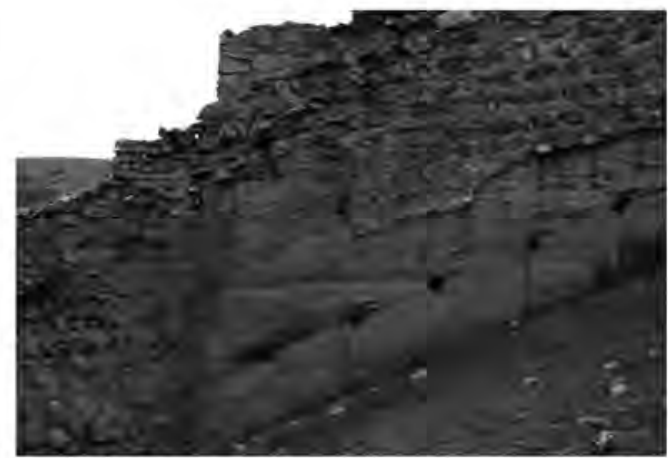

Figure 8. Rammed earth wall in the Coracha of the castle of Caracena (Credits: Author).

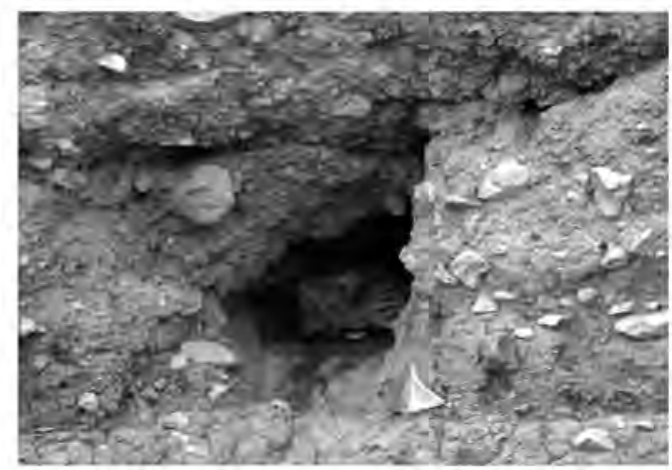

Figure 9. Crossbeam in a putlog hole of the coracha in the castle of Caracena (Credits: Author).

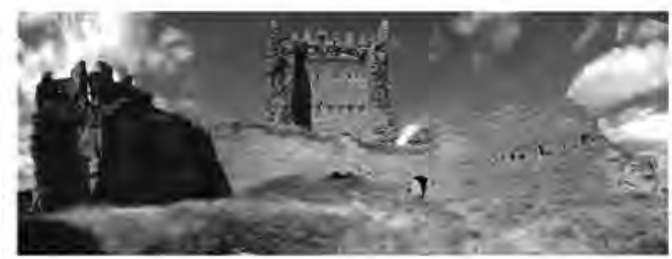

Figure 10. Castle of La Raya. Interior courtyard and the tower. The gate is placed in the right of the tower. The south wall (left) has a earth rammed filling (Credits: Author).

\section{CONCLUSIONS}

The use of the rammed earth in the late medieval castles of Soria is only two cases in which the castle is entirely built with this technique-Serón de Nágima and Yanguas - and a few other cases where rammed earth walls are coated with stone masonry. In this paper four of them have been 


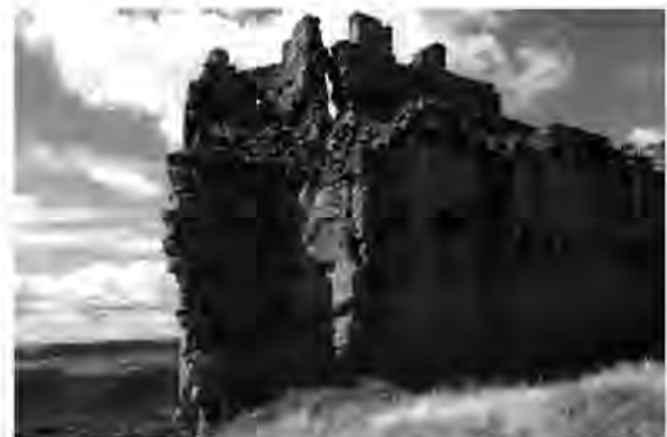

Figure 11. Castle of La Raya. South cylindrical turret in which it can be seen the putlogs holes in the rammed earth filling. The ceiling of the putlogs holes are made with a stone put over the beam, as in the near castles of Serón de Nágima and Monreal de Ariza (Zaragoza, Aragón) (Credits: Author).

analyzed: the Rollo tower in the walls of Agreda, the turret of the castle walls of Arcos de Jalon, the coracha and part of the south wall of the castle of Caracena, and the filling of the south wall of the Martin González tower or castle of La Raya. However, there are other cases where there are remains of rammed earth walls embedded in stone masonries, as is the case of Berlanga de Duero.

Through the studied cases, we have seen that in some castles the earth has been used as a filling of a stone masonry wall, while in other cases, it seems that on an ancient rammed earth wall has been overlapped a coating of stone so that repairs, protects and re-new the older wall.

The building of the castles of Serón de Nágima and Yanguas are different. While in Serón there are passant crossbeams and the earth constructive rows have no vertical joints, in Yanguas the needles are smaller and superficial and the formwork of the wall is organized in parallelepiped boxes. In Seron castle the earth masonry is also calicastrada. In both cases, the upper crenellated and the parapet walk were performed with stone and mortar masonry that protects the top of the rammed earth walls from erosion.

The study of the construction techniques of medieval defensive architecture is fundamental to, by establishing chronological and constructive types, propose an approximate dating when there are no architectural, aesthetic or documents that yielded that information.

\section{REFERENCES}

Benito Martin, F. 2008. «La ciudad de Ágreda y sus murallas». En Arqueologia y territorio medieval 2, 99-114.
Bernad Remón, J. 1994. Castillos de Soria, León: Lancia Casa Martinez. Carlos de la et al 1990. Castillos de Soria: aproximación a la arquitertura militar medieval. Valladolid: Universidad Internacional Alfonso VIII. Fundación Cảnovas del Castillo.

Cobos Guerra, F. \& Castro Fernández, J.J. 1998. Castillos y fortalezas. Castilla y León. León: Edilesa.

Cooper, E. 1991 Castillos señoriales en la Corona de Castilla. 3 vols. Valladolid: Junta de Castilla y León, Consejeria de Cultura y Turismo.

Diago Hernando, M. 1987. Expansión señotial en la tierra de Soria en la época Trastamara. Celtiberia 74 201-238.

Espinosa de los Monteros, J. \& Martin-Artajo Saracho, L. 1974. Corpus de los castillos medievales de Castilla. Bilbao: Clave

Fraile Delgado, M. 2005. Materiales de construcción en los castillos de Castilla y León. Ph. D. Dissertation. Madrid: Universidad Politécnica de Madrid

Gaya Nuño, J.A. 1935. La muela de Ágreda. Restos de la Almedina fortificada y de la Aljama hebrea. Boletín de la Real Academia de Historia (106): 271-285

Gil Crespo, 1.J. 2011. Fundamentos constructivos de las fortificaciones bajomedievales en la provincia de Soria: fábrica de mampostería con verdugadas de ladrillo en el castillo de Arcos de Jalón. In Huerta, S. \& Gil Crespo, I.J. \& García Suảez, S. \& Taín Guzmán, M. (eds.), Actas del Séptimo Congreso Nacional de Historia de la Construcción. Madrid: Instituto Juan de Herrera:

Gil Crespo, I.J. 2012. Rammed earth walls in Serón de Nágima castle (Soria, Spain): constructive lecture. In Mileto, C. \& Vegas, F. \& Crisitin, V. (eds.), Rammed Earth Conservation. Londres: Taylor \& Francis.

Gil Crespo, IJ. 2013. Fortificación fronteriza y organización territorial medieval: los castillos de Soria. In Proceerlings of the Congreso Internacional sobre Doctmentación, Conservación, y Reutilización del Patrimonio Arquitectónico, Madrid 20-22 de junio de 2013.

Jaquin, P. \& Augarde, C. \& Gerrard, C. 2007. Historic rammed earth structures in Spain, construction techniques and a preliminary classification. International Symposium on Earthen Structures, Bangalore, August 2007.

Lorenzo Celorrio, A. 2003. Compendio de los castillos medicvales de la provincia de Soria en el que se incluyen torres y atalayas de la misma época. Aumentado con las trazas de los ejemplares más representativos y adornado con ilustraciones de aquéllos que conservan restos significativos. Soria: Diputación Provincial de Soria.

Rubio Semper, A. 1990. El Jalón en la Edad Media. In Argente Oliver, J.L. (ed.), El Jalón, via de comunicación. Soria Junta de Castilla y León. Consejeria de Cultura y Bienestar Social, Museo Numantino.

Zamora Lucas, F. 1960. La torre de Martín González. Celtiberia (20), 153-165.

Zamora Lucas, F. 1969. Dos fortalezas sorianas en la frontera aragonesa: Serón de Nágima y Vozmediano. Castillos de España $(64) \div 29-38$. 